Do international organizations really shape government solutions in developing countries?

\author{
Matt Andrews \\ CID Working Paper No. 264 \\ August 2013 \\ (C) Copyright 2013 Andrews, Matt, and the President and Fellows \\ of Harvard College

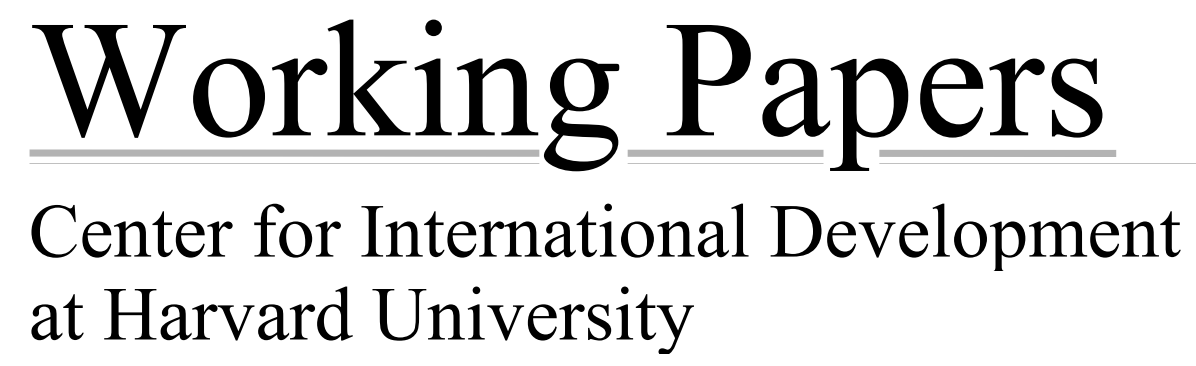




\title{
Do international organizations really shape government solutions in developing countries?
}

\author{
Matt Andrews \\ Harvard Kennedy School \\ 116 Rubenstein, 79 JFK Street \\ Cambridge, MA, 02138, USA \\ Matt_andrews@hks.harvard.edu
}

\begin{abstract}
International organizations like the International Monetary Fund and World Bank have been supporting reform initiatives in developing country governments since at least the 1980s. Various authors have criticized this support, arguing that international organizations use their influence to impose common models of government on developing countries - infringing on the sovereignty of these nations and frustrating domestic processes of finding and fitting government structures to local contexts. Some suggest that a modern new public management model of government is being imposed on developing countries, whereas others claim that developing countries are being forced to adopt a broad-brush neoliberal script. Such claims are seldom reinforced by empirical evidence showing the extent or nature of this influence, however. This leaves one asking, "Do international organizations really shape government solutions in developing countries?" This article explores such question and finds that international organizations do have a major (and growing) influence on government structures in developing countries and that this influence does impose a common model on these countries.
\end{abstract}




\section{Introduction}

International organizations like the International Monetary Fund and World Bank have been supporting reform initiatives in developing country governments since at least the 1980s. Various authors have criticized this support, arguing that international organizations use their influence to impose common models of government on developing countries-infringing on the sovereignty of these nations and frustrating domestic processes of finding and fitting government structures to local contexts. Some suggest that a modern new public management model of government is being imposed on developing countries, whereas others claim that developing countries are being forced to adopt a broad-brush neoliberal script. ${ }^{1}$ Such claims are seldom reinforced by empirical evidence showing the extent or nature of this influence, however. This leaves one asking, "Do international organizations really shape government solutions in developing countries?” This article explores such question and finds that international organizations do have a major (and growing) influence on government structures in developing countries and that this influence does impose a common model on these countries.

The article comes to these findings by examining the content of all World Bank projects in the Public Administration, Law and Justice (PAL\&J) sector since the 1950s. This study is made possible because of the public availability of the organization's project database. This obviously does not allow a complete perspective on the work of all international organizations but it is likely to provide a sufficiently reliable view given the prominence of the World Bank in the development community. The World Bank has arguably dominated both the intellectual space and applied project and loan activity surrounding government reform in this community. As a result of this role, patterns emerging in World Bank reform engagements are likely to be representative of broad behavior in the international development community.

The article has three sections. The first provides some basic background on the thinking behind public sector reform in development, noting how it emerged in response to new institutional arguments that 'rules of the game' in governments impacted growth prospects of developing countries. This section also introduces readers to World Bank projects in the PAL\&J sector, noting that these operations typically embedded various kinds of government reform activities. A second section looks at the emerging of the government reform agenda, as supported

\footnotetext{
${ }^{1}$ Andrews 2010; Chang 2003; Kenny 2008; Rodrik 2007; Rose 2003.
} 
by international organizations like the World Bank. Evidence presented here shows that external influence is wide spread across all countries and had been growing - in numbers of projects and value of engagement. This shows that organizations like the World Bank are increasingly shaping the ideas, opportunities, demand and supply of public sector reform in developing countries. A third section then shows that the projects and interventions look remarkably similar across the very different sets of countries affected. Countries are commonly supported in creating governments that are market-friendly, disciplined, and modernized; with specific types of common interventions introducing reforms like privatization, civil service modernization, the creation of autonomous agencies, and more.

A conclusion points out that this model is reinforced by indicators that define 'good' or 'accepted' or 'right' rules of the game in governments in developing countries. The discussion does not decry or endorse the particularities of this common model of externally sponsored reform. It simply notes that it exists and is reflected in patterns of World Bank project data. The conclusion points to a needed analysis of the implications of this finding by asking a simple question: "What does it matter if international agencies are defining governmental solutions in developing countries?"

\section{New institutional economics and government reform in development}

The language and theory of new institutional economics has framed public sector reform since the 1980s. This theory posits that society consists of formal and informal rules - institutionsthat shape incentives people and organizations have to behave. ${ }^{2}$ Governments are the hub of many such rules, bound by some and the maker and enforcer of others. These are the 'rules of the game' that shape a government's size, scope, operation and influence on society.

Theorists claim that different institutions create incentives for different behavior, leading to different outcomes. In shaping behavior, theorists claim that different institutions have different affects on economic progress. The key to development, as this argument suggests, is "finding the right institutional framework" or 'rules of the game'. ${ }^{3}$ Governments have been the focus of such search in development. As a result, much government change is called 'public

\footnotetext{
${ }^{2}$ North 1990.

${ }^{3}$ Yeager 1999, 113.
} 
sector institutional reform' and "involves fundamental changes in governmental "rules of the game""' towards those considered 'right' for development. ${ }^{4}$

In developing countries, such reform is frequently influenced by external entities like the World Bank, regional development banks and bilateral agencies. ${ }^{5}$ This influence manifests in many ways. It comes through external identification of what the 'right rules' are, as well as through financing, facilitation and sometimes even implementation of interventions intended to introduce such rules. Projects and loans are the primary vehicle organizations like the World Bank have to exercise such influence. Public sector reform projects are distinct from many activities in organizations like the World Bank, however, given that these interventions are within developing country governments, intended to change governments themselves. Spending in such operations is typically classified as falling in the Public Administration, Law and Justice sector (PAL\&J). ${ }^{6}$ Other engagements by external organizations involve interventions that may be carried out through governments but effect change and disburse money elsewhere-expanding infrastructure through new road construction, for example, or financing agricultural production. ${ }^{7}$

There are various kinds of externally influenced public sector institutional reforms in developing countries. These can be identified by looking at the themes or activities routinely carried out in World Bank projects in the PAL\&J sector. Most obvious are those activities reflected under the major theme, Public Sector Governance. These include efforts to change administrative and civil service systems, public expenditure, financial management and procurement processes, and tax policy and administration mechanisms. They also include initiatives to decentralize and address corruption in governments.

Public sector institutional reforms embedded in PAL\&J operations also address the way governments engage with society and the broader economy. These are reflected in major World Bank project themes like Economic Management, Financial and Private Sector Development, Rule of Law, and Trade and Integration. Activities under such themes specifically target the rules of government intervention in a country's economy. They attempt to change institutions that

\footnotetext{
${ }^{4}$ World Bank 2000: vii

${ }^{5}$ And others, like the Asian, African and Inter-American Development Banks (ADB, AfDB and IADB), International Monetary Fund (IMF), Swedish Institute for Development Assistance (SIDA), British Department for International Development (DFID), and United States Agency for International Development (USAID).

${ }^{6}$ The focus on PAL\&J loan numbers reflects an approach used by Moloney (2009).

${ }^{7}$ These operations are classified according to where spending is focused on making a change - in the Transportation sector, for instance, or Agriculture.
} 
determine what productive assets governments are allowed to own and manage, for example, how public organizations regulate private firms, what governments do to influence trade, whether these organizations can incur debt, and so forth.

A third sub-set of public sector institutional reforms focuses on the way 'rules of the game' impact core development agendas like health, education, rural and social development and the environment. Interventions in these thematic areas blend changes to internal rules of government operation and external rules of public sector engagement with outside entities. Civil service rules can be adjusted to address gender issues and public finance laws can require participation in the budgetary process, for example, which further the Social Development theme. Health system performance is similarly affected by both types of institutional reform. For example, adjustments to internal public sector rules about medicine procurement and storage are commonly paired with regulatory changes that determine who can access and use medicinesinside and outside government. As with interventions in Public Sector Governance and Financial and Private Sector Development thematic areas, such reforms are intended to introduce the 'right rules' needed to create governments that better facilitate development and economic growth.

\section{The emergence and reach of these reforms}

The idea that development can be facilitated by adjusting governmental 'rules of the game' is relatively new. Externally influenced public sector institutional reform is a recent addition to development as well. This may be surprising because developing country governments have received external assistance since the 1940s. Some early assistance did build organizational capacities like development banks, but it was not really focused on reforming governmental entities. This is evident when one considers that only 18 of the 2,782 World Bank projects started before 1980 were classified as explicitly benefitting the PAL\&J sector. ${ }^{8}$ This is less than 1 percent of Bank operations in the period. ${ }^{9}$ The low numbers reflect a policy of non-political engagement that dominated international development. This policy kept many external development organizations out of the business of government. They focused instead on building

\footnotetext{
${ }^{8}$ This is based on the classification of bank projects to that time. This classification typically only noted the lead sector in which the project supported spending, which is different from the classification in latter periods. Projects initiated after the early 1980s typically identified more than one sector of engagement.

${ }^{9}$ Another 66 projects in this period had a multi-sectoral focus and may have had a public sector reform component. Adding these to the projects explicitly focused on PAL\&J would yield 3 percent of Bank lending in the period.
} 
infrastructure and productive economic sectors. Over 750 World Bank projects before 1980 sought to strengthen rural infrastructure and agriculture sectors, for example. ${ }^{10}$

Things started to change in the mid to late 1970s. Organizations like the World Bank began recognizing developing country governments as major players in development. This was largely because many developing country governments had grown since the early 1950 s to dominate their domestic economies as the main employer and fiscal presence. Governments involved themselves in all areas of development-from agriculture and the rural economy, through transportation, energy and telecommunications, and into the financial sector where public sector banks were common. A World Bank report of the time noted that, "The public sector now appears to be as important in developing countries as in industrial countries."11

Public sectors were in turmoil during this period. Crises in the 1970s generated stubborn recessions that bled into the 1980s and upset global financial and commodity markets. Many developing country governments experienced difficulty following such crises, facing economic problems that domestic means could not solve. These problems frequently spilled over into social and political tension. Such tensions provided entry points for external organizations to engage in public sector reform. Chile's first World Bank PAL\&J operation was approved months after the crisis-induced Pinochet coup in 1974, for instance. Senegal's externally supported government reforms began months after 1977's presidential election, which was the first to be contested since 1963 (reflecting economic and political pressures of the time). Argentina, Bolivia, Ghana, Haiti, Mozambique, Thailand and Uganda are other early examples of countries in which World Bank reforms began because of crisis and a change in regime.

These countries accepted externally influenced public sector reforms because the associated finances were required to maintain stability. Newly formed administrations also hoped engagements with organizations like the World Bank would enhance their government's legitimacy. This was vital for raising finance through debt, attracting foreign direct investment, and otherwise engaging in a globalizing world economy. Perhaps part of this signaling effort, over 100 World Bank PAL\&J projects in the 1980s were called 'adjustment' programs. ${ }^{12}$ These sought primarily to stabilize unstable government finances. They also introduced substantive

\footnotetext{
${ }^{10}$ This information is based on analysis of projects in the World Bank project database, conducted by the author.

${ }^{11}$ World Bank 1988, 5.

${ }^{12} 76$ projects had 'Structural Adjustment' in the title. Another 50 had the word 'Adjustment' in the title.
} 
change to the way public sectors looked, how large they were, what they did, and how they operated. Adjustment operations comprised a significant portion of the 469 World Bank projects focused at least partly on public sector reforms in this sector in the decade. These accounted for about 20 percent of World Bank loans in the 1980s, indicating the emerging importance of externally supported public sector reforms in development at the time. These reforms were an integral part of the growing 'Washington Consensus' that embraced discipline and controlled governments as a valuable norm and model for developing countries.

The importance of public sector reforms continued to grow into the 1990s. PAL\&J activities were present in over 1,700 World Bank projects in the 1990s (62 percent of operations). ${ }^{13}$ Some countries saw extant reform agendas accelerate. Five new PAL\&J projects were approved in Chile in 1991 alone, for example, eclipsing the total of such projects prior to 1989. This, coincidentally, was the year after Pinochet's administration was replaced. Reforms were similarly embedded in five new projects in Mozambique in 1993 - all approved in the six months following October 1992's peace accord. Many countries began reform engagements with external organizations for the first time as well. Nearly 400 World Bank PAL\&J projects in the 1990s were in Europe and Central Asia, where countries from the former Soviet Union and Yugoslavia provided a green field for large scale government reform. ${ }^{14} \mathrm{New}$ governments were being born in this period and external support was vital to these birthing processes. The first World Bank operation in Georgia was 1994's Institution Building Credit (IBC), for instance. It aimed "to assist the Government of Georgia (GOG) to move to a private market economy by strengthening public institutions."

The 2000s saw many countries building on early external reform engagements, which was one driver of an additional 3,235 new World Bank projects with PAL\&J content in the period ( 65 percent of all operations in the decade). Some countries initiated such engagements for the first time in this period, however. Afghanistan is the obvious example. The World Bank targeted government reform in 12 projects during 2002 and 2003 alone, the years immediately following initial intervention by the United States. Nation building in places like Afghanistan has proven a fertile ground for externally supported public sector reforms. These activities have been evident in an additional 37 World Bank projects in Afghanistan since 2003. They are

\footnotetext{
${ }^{13} 1,724$ projects had some spending in the PA\&J sector, out of 2,751 in the decade.

${ }^{14}$ Only 21 projects in this region had any kind of public sector reform focus in the 1980s.
} 
incorporated into 26 operations in Georgia since the Rose Revolution (also in 2003) and feature in 14 engagements in Haiti after the 2004 Rebellion that bought René Preval to power.

\section{The pervasive nature of these reforms}

The steep growth in public sector reform operations in the last twenty years has meant that this kind of intervention is now common. The World Bank had supported 13,121 projects as of April 2011; 5,981 of these included some activity in the PAL\&J sector. One can reasonably expect some emphasis on public sector reform in most of these projects. Essentially, therefore, nearly one in two World Bank projects has included activities potentially focused on such reform. ${ }^{15}$ This exceeds the World Bank project focus in any other sector. ${ }^{16}$

PAL\&J project costs are lower than those in the other areas, given less-expensive activities, but resources committed to this sector are still substantial—amounting to $\$ 188.5$ billion since the World Bank's inception. ${ }^{17}$ This is only World Bank spending, of course. A full accounting would lead to larger numbers, including costs of activities by the International Monetary Fund (IMF), regional development banks, bilateral agencies, professional groups like the International Federation of Chartered Accountants, and more. One wonders if anyone in 1980 or 1982 ever expected such a large externally influenced public sector reform industry to develop in this time.

The pervasive nature of this kind of reform is further evidenced in the variety of affected countries. A random sample of 40 countries was identified to examine whether these interventions are peculiar to some contexts or in place across all contexts. It includes Afghanistan, Algeria, Angola, Argentina, Azerbaijan, Bolivia, Bulgaria, Burundi, Cape Verde, Central African Republic, Chile, China, Georgia, Ghana, Guinea, Haiti, Honduras, Kyrgyz, Laos,

\footnotetext{
${ }^{15}$ PAL\&J spending occurred in $45.83 \%$ of all World Bank projects. This shows a rise in the past few years, given that these projects made up 39 percent of the 10,500 projects in place when Moloney (2009) did her study. Over 70 percent of the projects approved since Moloney's study had PAL\&J content, reflecting the uptick in this activity she discusses and later sections of this chapter also identify.

${ }^{16}$ Consider, for example, that less than a third of World Bank projects incorporated some focus on the agricultural sector. Less than one in five projects disbursed resources in each of the education, health, transportation, electricity and water sectors.

${ }^{17}$ When counting the PAL\&J portion of every project, at the current value at the time each project was approved, PAL\&J costs amount to about $\$ 188.5$ billion. Total costs for all 13121 projects amount to $\$ 1.3$ trillion. The PAL\&J portion is thus about 14 percent of the total.
} 
Madagascar, Malawi, Mauritius, Moldova, Mongolia, Mozambique, Nicaragua, Niger, Poland, Rwanda, Samoa, Senegal, Serbia, Sri Lanka, Tanzania, Thailand, Togo, Uganda, Ukraine and Uruguay.

Even with such variation in the sample, all countries shared the experience of having undergone World Bank sponsored public sector institutional reform by 2004. Twenty seven countries had started these reforms before 1990, 11 began in the 1990s, and 2 only initiated such activities in the 2000s. ${ }^{18}$ The latecomers were former Soviet and Yugoslav countries and/or countries emerging from conflict like Afghanistan in 2002. These countries tended to have fewer projects embedding some kind of public sector reform, but the median across the full sample was still high at 44. The median cost of such interventions was $\$ 633$ million. Specific examples give these figures some texture and show the different contexts across which these reforms have traveled. Consider Togo, for example, a French speaking West African country of 6.6 million people (in 2009) and a per capita GDP (in 2008) of less than $\$ 800$ (about $\$ 2$ a day). ${ }^{19}$ It has had 32 projects with public sector reform content since 1980 at an overall cost of $\$ 378$ million. Similarly sized Laos, an East Asian nation with average incomes of about $\$ 2,000$, engaged with the Bank in 48 projects incorporating aspects of government reform since 1989, costing \$535 million. Argentina, a larger Latin American nation with over 40 million people and per capita GDP of about $\$ 13,000$, has embarked on 125 such projects carrying a price tag of over $\$ 13$ billion since 1980. East Africa's Uganda, an Anglophone nation, also had its first project in 1980 and has adopted 97 projects since then, costing over \$2 billion. The average daily income of its 32 million inhabitants was about $\$ 3$ in 2008. Poland, a newly considered upper income country with about 40 million citizens, had 34 World Bank supported projects of this type between 1990 and 2010. These cost over $\$ 4$ billion.

\section{A common model of the 'right rules' of government}

The pervasive nature of externally influenced public sector reform in development is impressive; especially considering these reforms emerged only recently. Government reform is now influenced by external development organizations in countries of all types and in all

\footnotetext{
${ }^{18}$ The 'start date' coincides with a country's first project classified in the PAL\&J sector.

${ }^{19}$ Based on constant dollar measures, adjusted for purchasing power parity (taken from the World Development Indicators database).
} 
regions. The growth in project numbers suggests this influence has grown over time as well. Organizations like the World Bank are increasingly shaping the ideas, opportunities, demand and supply of public sector reform in developing countries.

Many would expect the nature of reform to vary across the wide range of contexts in which it is found. This reflects beliefs that the 'right rules' are different for different contexts. Such sentiment is regularly voiced in the formal pronouncements on reform by development organizations like the World Bank. These typically decry attempts at generalizing government reform solutions. A 1992 World Bank governance document notes, for example, that, "The institutional characteristics for managing development [varies] widely among countries and do[es] not permit easy generalization." ${ }^{20}$ Ahrens writes similarly that, "[T]here are still no clear or settled ideas about how effective governance should be suitably defined, let alone how key governance issues can be appropriately incorporated into externally-financed programmes of policy reform." ${ }^{21}$

A different set of observers argue that generic models do in fact exist and dominate reform designs supported by entities like the World Bank. ${ }^{22}$ Some refer to a strong neoliberal influence on such. ${ }^{23}$ Others infer that interventions commonly impose modern managerial solutions on developing countries. The inferences are seldom supported by empirical research beyond isolated case studies or loose references to large sample reform experience. An example of the latter is the 2008 Independent Evaluation Group analysis of World Bank public sector projects. ${ }^{24}$ This argued that reforms are "likely to be one size fits all" but does not show evidence for such or explain what the generic model looks like.

This article aims to go beyond such statements, using information from the World Bank project database that allows more empirical analysis of the issue. The empirical analysis is possible because one can see themes addressed in over 5,000 projects focused on PAL\&J sector change. Thematic references facilitate analysis of the degree of common content in reforms across countries. One can see which themes are most frequently

\footnotetext{
${ }^{20}$ World Bank 1992, 7.

${ }^{21}$ Ahrens 2001, 54.

${ }^{22}$ Andrews 2005, 2008, 2009, 2010, 2011, 2013; Chang 2003; Grindle 2004; Rodrik 2007.

${ }^{23}$ Rodrik $(2007,182)$ refers to a bias towards designing institutional reforms reflecting a "“"neoliberal" socioeconomic model."

${ }^{24}$ World Bank 2008, 38.
} 
referenced across all World Bank PAL\&J projects. One can also see, especially in the smaller sample of 40 countries already introduced, if any themes are addressed in all countries and if the timing of reforms is similar across countries.

Such analysis yields a picture of reform that does differ to some degree across countries. For example, a few countries' reform agendas have given prominence to reforms focused on conflict prevention and post-conflict reconstruction. Another small set of countries have recently emphasized transforming government to enable responses to global food crises. Even with such peculiarities in reforms, however, most countries have a lot in common. When analyzed, about two thirds of each country's externally influenced reforms reflect a generic set of solutions - implying that the 'right rules' are largely the same across different contexts. These 'right rules' aim to establish market friendly, disciplined and modernized, formal and depoliticized governments.

\section{Market-friendly 'rules of the game' are common}

Externally influenced public sector institutional reforms frequently and commonly target change in government structures considered necessary for market development. Such reforms are classified as 'Financial and Private Sector Development', 'Rule of Law' ${ }^{25}$ and 'Trade and Integration'. These themes emphasize changes to rules, processes and structures at the interface of the public and private sectors. Activities include privatizing state enterprises, deregulating sectors, creating laws that liberalize trade, and establishing government entities to promote competitive markets. They are a focal point in 44 percent of all PAL\&J projects. ${ }^{26}$ This indicates that about one out of every two public sector reform projects addresses such issues. The likelihood of a country pursuing such reform is 100 percent, given evidence that all 40 of the sample countries had interventions like this.

Different governments pursued similar activities in such reforms as well. Eight kinds of activities were common to all forty countries' reform agendas, and five of these activities

\footnotetext{
${ }^{25}$ Especially the sub-theme titled 'Legal Institutions for a Market Economy' which dominates the major theme.

${ }^{26}$ This reflects 2,432 projects with at least one major thematic reference to 'financial and private sector development', 'rule of law' (especially 'legal institutions for a market economy'), and 'trade and integration'. There were 1,884, 555 and 652 references to each of the three major themes, respectively, out of 5,610 references in total.
} 
were related to market-friendly reforms. All 40 countries changed government structures to better provide infrastructure for private sector development, for example. This included interventions like customs reform or adjustments to the way the transportation or water ministries worked. ${ }^{27}$ All of the countries also changed some aspect of regulation and competition policy, commonly deregulating and liberalizing sectors. Furthermore, every single country privatized at least one industry in the course of World Bank PAL\&J projects and they all used these operations to introduce 'legal institutions for a market economy'. Three of four countries also took steps to introduce government structures to support better financial reporting standards in private organizations, promote exports, and facilitate trade.

It is particularly striking that these reforms are typically pursued early on in all countries' reform journeys. This is apparent when one breaks reform experiences down into defined periods, of mostly two years in duration, and identifies which period a particular country started its public sector reform journey in and what countries did in this and the ensuing periods. ${ }^{28}$ Azerbaijan's PAL\&J reforms began in 1994, for example, and 37 projects with 151 themes have been pursued in nine periods since then. ${ }^{29}$ Afghanistan had its first public sector reform in 2002. It initiated 56 projects addressing issues in 184 thematic areas in the five ensuing periods. In both examples the first three to four periods of reform (or 6 to 8 years) were dominated by activities establishing the rules of market-friendly government. At the extreme, 12 of 14 themes addressed in Azerbaijan's first two years of reform involved public sector adjustments intended to facilitate financial and private sector development. The experience is similar across all 40 countries - as summarized in Figure 1.

\footnotetext{
${ }^{27}$ Algeria's National Water Supply and Sewerage project is an example. Initiated in 1987, this project sought to improve the functionality of the country's water sector to support the construction industry and allow water access for expanding markets.

${ }^{28}$ Projects before 1980 and projects between 1980 and 1989 were also considered falling into separate periods. Pre1970 s projects were isolated from the rest because of their peculiar status as initial experiments and the 1980s period was separated from the others because about 500 projects were initiated in this time. Periods were identified every two years after this, given that about 500 projects started every two years.

${ }^{29}$ It undertook three projects in the first period (1994 to 1995), two in the following period (1996 to 1997), seven in the two years thereafter (1998 to 1999) and four in the early years of the new century (2000-2001). The country initiated 4, 3, 6, 7 and 1 projects in each of the following five two-year periods.
} 
Figure 1. Percentage of countries adopting Market-Friendly reforms, by period

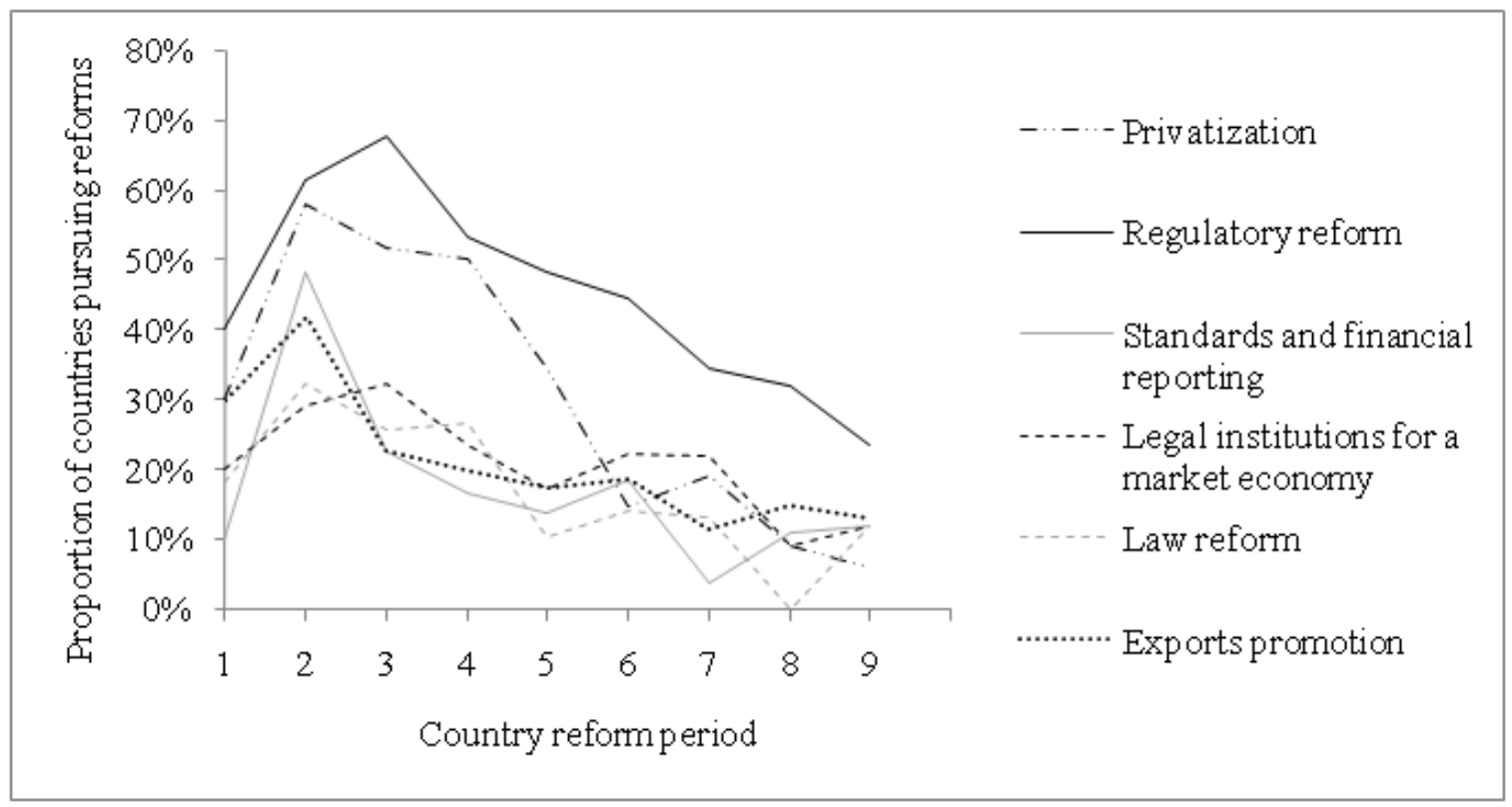

Source and note: Author's calculations of World Bank project histories in 40 randomly selected countries.

The figure shows that most countries privatized industries, de-regulated markets and introduced rules, policies and structures facilitating market activity and trade in the early reform stages. By the third period of each country's reform experience (which typically spans ten periods) 90 percent of the countries had privatized and begun de-regulating some sector of the economy. ${ }^{30}$ At this point, about 80 percent of the countries had also introduced institutional changes to facilitate exports and competitiveness and started a government-led effort to adopt international accounting and reporting standards in the private sector. These kinds of activities tailed off in later reform periods.

This evidence suggests that market friendly 'rules' are a key and consistent element of externally influenced government reforms. They are not only the generically relevant 'right rules' to adopt in reforms but are the common 'right rules' to start reform with - in all countries, no matter when the start date is or what the context looks like. This view is borne out in evidence of reform in Chile in the 1970s, Uganda in the 1980s, Azerbaijan in the 1990s, and Afghanistan in the 2000s (and beyond). Institutional reform starts in all cases with an emphasis on limiting the scope of government vis-à-vis the private sector and

\footnotetext{
${ }^{30}$ Only four of the 40 countries (Angola, Niger, Samoa and Angola) had not initiated a privatization through reforms in the first three periods, for example. Only four (Bulgaria, Haiti, Kyrgyz and Sri Lanka) did not use the first three periods to de-regulate and improve competition policy.
} 
focusing government on supporting the private sector. Using the soccer analogy introduced earlier, the new 'rules of the game' decrease the field in which government is played and ensure that the game of government is supportive of private sector players and play.

\section{New rules discipline and modernize governments}

Externally influenced reforms also commonly emphasize creating governments that are disciplined and modernized. Such interventions are reflected in the 'Economic Management', 'Public Sector Governance' and 'Urban Development' themes. Activities typically classed as 'Economic Management' include steps to limit political influence over monetary, fiscal and debt policy and force discipline and control in these areas. ${ }^{31}$ They are reinforced by 'Public Sector Governance' efforts to modernize public financial management, civil service and tax administration systems, promote anti-corruption and decentralize service delivery. 'Urban Development' interventions build on decentralization initiatives to promote disciplined, modern urban governments.

Over 3,000 projects focus on one or more of these types of initiatives- -53 percent of all operations in the PAL\&J sector. ${ }^{32}$ One in two World Bank PAL\&J projects thus target such changes. They are also widespread across countries, evident in all 40 nations in the sample. Public financial management (PFM) and administrative and civil service reforms (ACSR) are most common, both included multiple times in the reforms of 39 out of the 40 nations. The average country had twelve projects with a PFM focus and 7 with an ACSR emphasis. Decentralization and municipal institution building are also common. They feature in over 80 percent of the countries' reform journeys, as do activities involving macroeconomic and debt management reform.

Similar to market-friendly reforms, these interventions are introduced according to similar patterns. 'Economic Management' activities appear early in reform journeys, for instance. Figure 2 shows that about 40 percent of the sample countries implemented changes

\footnotetext{
${ }^{31}$ As in Malawi's 1990 Agricultural Sector Adjustment project, Moldova's 1993 Rehabilitation Loan project, and Haiti's Electricity Loss Reduction project.

${ }^{32}$ Economic Management was referenced as such in 640 projects. Public Sector Governance was listed as a theme at least once in 1,976 projects. Urban Development was identified as a major theme in 920 projects. Controlling for duplicated references, one finds 3,046 projects out of 5,610 citing one or more of the themes.
} 
to their economic and debt management mechanisms in each of the first and second periods of reform. Ninety percent of the countries had introduced some kind of economic management adjustment by the third period of reform. ${ }^{33}$ Fewer countries were engaged in such change in later periods - as was the case with market friendly reforms like privatization. These timing similarities suggest that economic management reforms go handin-hand with efforts to establish market-friendly government structures. In fact, both types of activities are often integrated in the same early period operations. ${ }^{34}$ Reforms that discipline government are thus related to reforms that liberalize the economy and foster market-friendly government. Both, many would argue, ${ }^{35}$ reflect neoliberal ideas that seem to be at the heart_ - and start — of externally influenced models of public sector reform.

Figure 2. When countries adopted Macroeconomic Management reforms

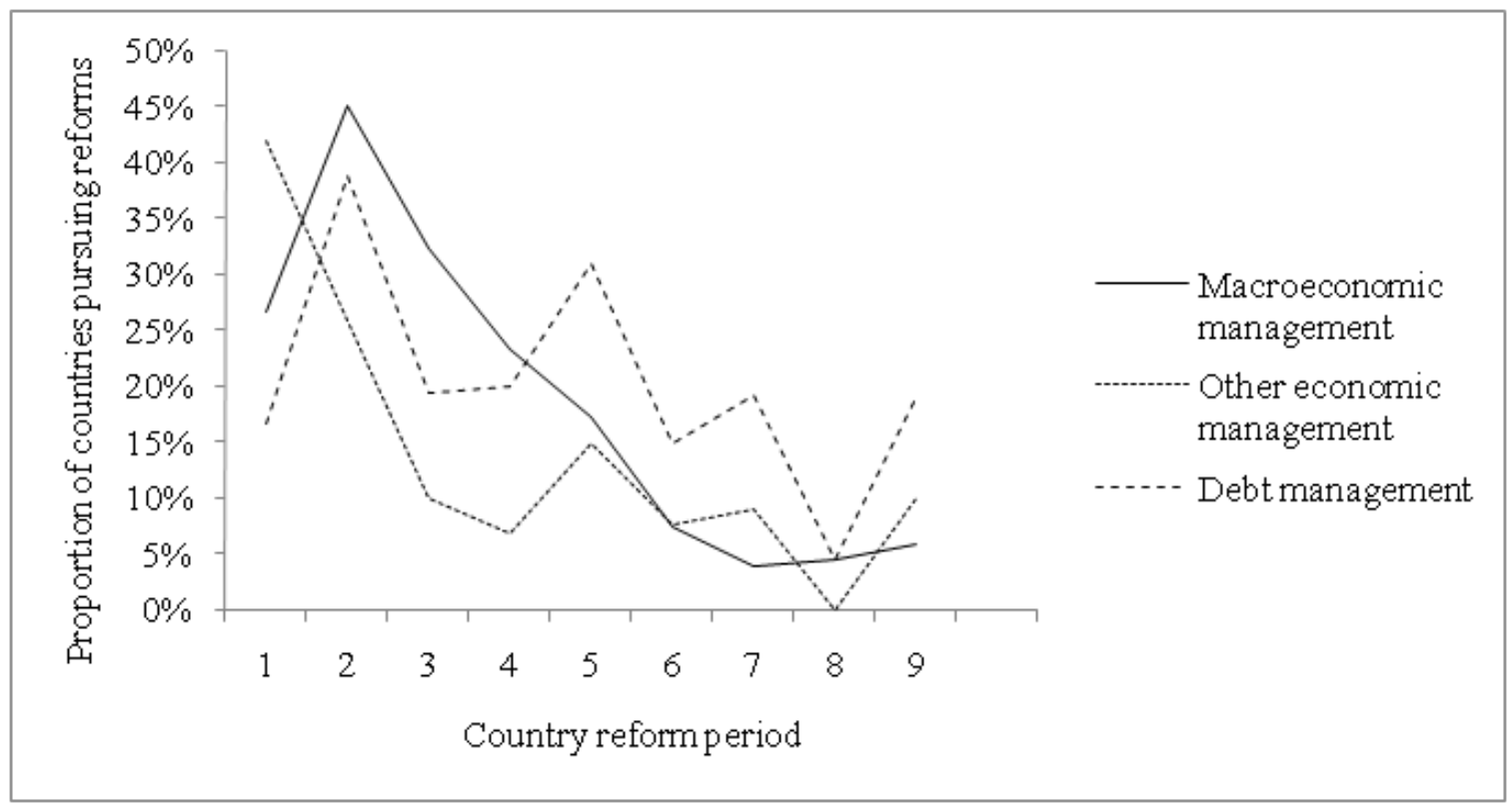

Source and note: Author's calculations of World Bank project histories in 40 randomly selected countries.

\footnotetext{
${ }^{33}$ Madagascar's 1989 Economic Management and Social Action project is an example. It formalized budget and fiscal policy processes and disciplined the public investment process. Mozambique's 1994 Second Economic Recovery Credit aimed to "develop a strong macro-monetary capability within the central bank" and ensure disciplined fiscal policy. Georgia's 1995 Rehabilitation Loan supported the government in developing an economic program to restore macroeconomic stability and liberalize prices. Bulgaria's 1996 Rehabilitation Loan helped the government strengthen the National Bank's monetary policy mechanisms. Moldova's 2001 Structural Adjustment Credit included budgetary controls.

${ }^{34}$ Madagascar's early fiscal policy reforms were aligned with efforts to liquidate or privatize public enterprises, for example. The Georgian operation identified above included initiatives to promote trade liberalization and privatization. Bulgaria's Rehabilitation Loan sought to improve monetary policy mechanisms and accelerate the privatization program. The Moldovan project targeted arrears management while also 'de-monopolizing and privatizing the energy sector.'

${ }^{35}$ Rodrik 2007.
} 
The emphasis on disciplined and modernized government is further reflected in the many reforms classified under the 'Public Sector Governance' theme. Figure 3 shows that these reforms feature prominently in all periods of reform in the 40 sample countries. About 80 percent of these governments had initiated some form of PFM change in the first two periods of their engagements with the World Bank. At least one PFM reform was also started in 80 percent of the countries in the most recent two periods. Similarly, more than 80 percent of the countries pursued civil service adjustments in the first two periods of their reform journeys. A similar proportion initiated new projects in the most recent two periods. This is not to say that reforms looked the same in all periods, however. There is evidence of what literature calls first and second generation designs in PFM and civil service reforms.

Figure 3. Percentage of countries adopting Public Sector Governance reforms, by period

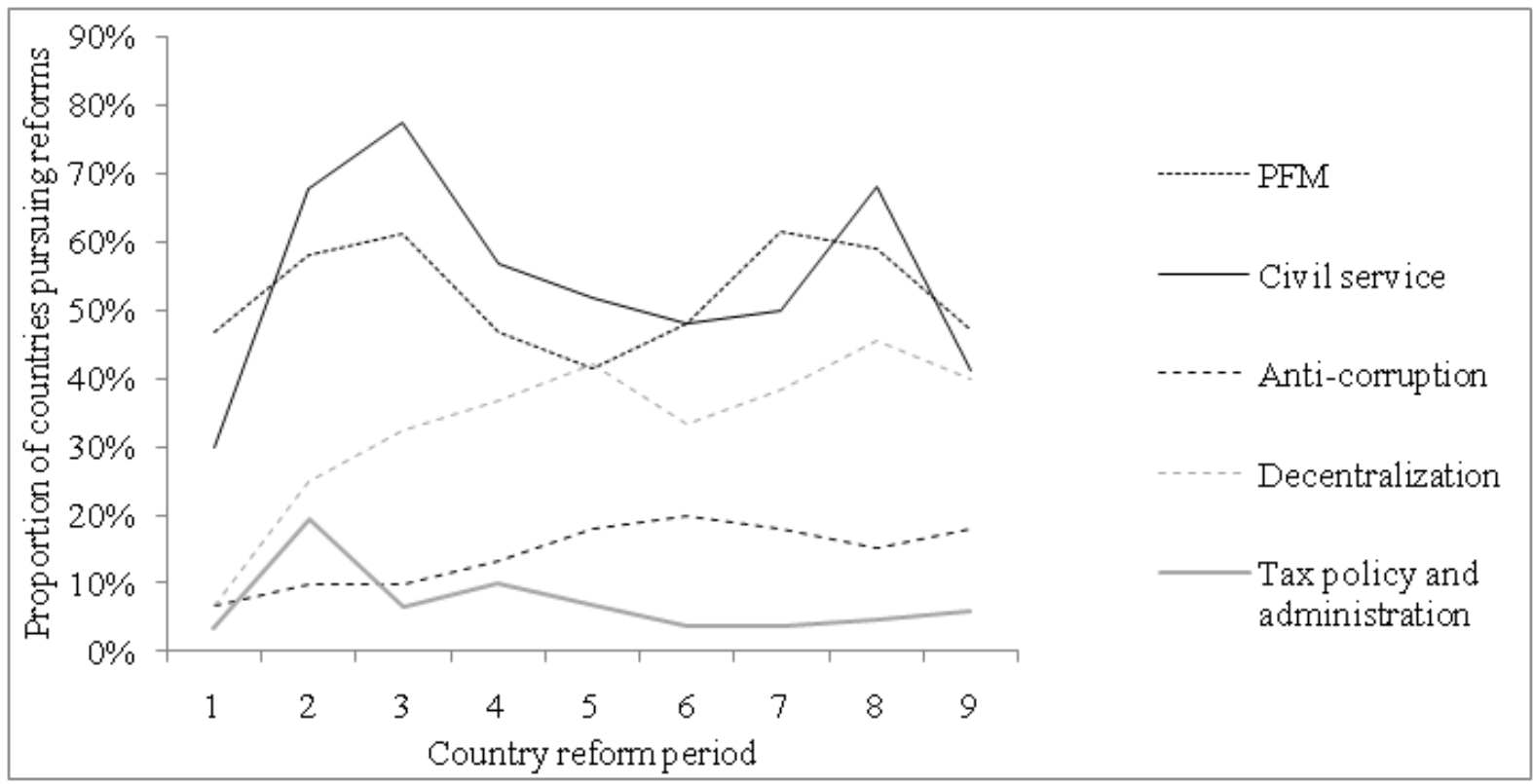

Source and note: Author's calculations of World Bank project histories in 40 randomly selected countries.

Early period reforms in most of the 40 countries look more like first generation interventions. ${ }^{36}$ These comprise efforts to bring centralized, ex ante control to public financial management and administration processes. ${ }^{37}$ They manifest in aggressive steps to

\footnotetext{
${ }^{36}$ The content of early period reforms with PFM and ACSR themes were analyzed to see if they exhibited first or second generation characteristics. 29 of the 40 countries' early projects were easily identified as being more like first generation reforms.

${ }^{37}$ First generation PFM reforms include the introduction of standardized annual budgeting and treasury processes, basic procurement rules and cash-based expenditure controls. First generation civil service reforms involved
} 
(inter alia) formalize budget processes, introduce cash controls, and rationalize the civil service wage bill — often through downsizing. One sees such initiatives in Argentina's 1991 Public Sector Technical Assistance Loan, Tanzania’s 1992 Parastatal and Public Sector Reform Project and the 2004 Second Emergency Public Administration Project in Afghanistan. They also characterize content in Lao's 1992 Structural Adjustment Credit and Georgia and Moldova's 1999 Structural Adjustment operations.

These initiatives look quite different to PFM and civil service reforms in later periods. Latter interventions are more 'second generation' in character, introducing modern management mechanisms into government and devolving accountability and control to enhance efficiency and effectiveness. ${ }^{38}$ Recent projects in Argentina, for instance, introduce performance management, monitoring and evaluation, e-government and other modern processes. ${ }^{39}$ Tanzania's 1999 Public Sector Reform Program is another example, focused on policy de-concentration, performance monitoring, and establishing meritocratic civil service processes. Afghanistan's most recent reforms introduce multi-year budgeting and other modern mechanisms. Laos, Moldova and Georgia have taken similar steps to adopt current best practice IT-based management systems, internal audit processes and medium-term expenditure frameworks.

By commonly front-loading first generation interventions, World Bank sponsored public sector reforms again seem to focus first on 'rules of the game' that control and discipline government. This is a hallmark characteristic of externally influenced public sector institutional reforms. No matter which country one is speaking of, rules that bring PFM and civil service discipline are 'right' and the 'right starting point' for reform. Only once control and discipline is established do projects turn to modernizing systems and mechanisms. Interestingly, the steps toward modernization are also common. In PFM, for example, more than 80 percent of the 40 countries have recently adopted multi-year budgets,

initiatives to control and rationalize the wage bill through downsizing and reorganization, formalization of pay and employment systems, and aggressive restructuring of administrative entities to minimize redundancy.

${ }^{38}$ Second generation reforms PFM comprise steps to adopt multi-year budgeting, IT-based financial management systems, modern internal audit and monitoring and evaluation systems, and even performance management mechanisms. Second generation civil service reforms include attempts to introduce merit-based hiring and compensation mechanisms, performance management and de-concentrated organizational structures.

${ }^{39}$ See the 2007 Second State Modernization project, for example. 
modern internal audit regimes, and other practices. ${ }^{40}$ Studies show such managerial reforms are pervasive across developing countries; perhaps even more than in developed nations. ${ }^{41}$ Additionally, more countries decentralize in later reform periods than in early periods, and most participatory reforms take place when countries have been improving governments for years. Both are examples of interventions that de-concentrate control and influence. They are focused on efficiency and effectiveness and not top-down bureaucratic command. In the one best way model of institutional reform they are important 'rules of the game' but only when the game of government has shown itself to be disciplined.

\section{The extent and significance of international organizations' impact on government}

The World Bank project database evidence discussed here shows that efforts to establish marketfriendly and disciplined modern governments dominate 72 percent of all PAL\&J projects. ${ }^{42}$ This content is the basis of a one best way model of externally influenced public sector institutional reform in development. This model is likely to characterize such reform in contexts as different as Afghanistan, Laos, Malawi, Moldova, Mongolia, Uganda and Uruguay.

It is interesting to note that the characteristics of such a model are reinforced by indicators of good government developed and used by international organizations, academics, and credit rating agencies. The Worldwide Governance Indicators (WGIs), for instance, claim their basis in "The norms of limited government that protect private property from predation by the state." 43 They relate the broadly held idea that good governance is built on "institutions that establish a predictable, impartial, and consistently enforced set of rules for investors." Countries receive WGI points for 'government effectiveness' where government is limited by law, business regulations are light and the civil service is subject to rules requiring meritocratic hiring. The following description reflects part of what the indicators portray as an 'effective government': 45

\footnotetext{
${ }^{40}$ Andrews 2011.

41 Kenny 2008.

424,091 projects cite at least one of these themes in describing reform activities.

${ }^{43}$ Kaufmann, Kraay and Mastruzzi 2007, 2.

${ }^{44}$ Knack 2000, 11.

45 Andrews 2008, 382.
} 
An effective government is small and limited in its engagement, formalized in mission and process and drawing limited revenues primarily from domestic sources. High-quality personnel devise and implement needed programs and deliver efficient and effective services via participatory processes and through formalized, disciplined, efficient and targeted financial management.

Responsiveness to the citizenry's changing needs is high, effected through transparent, decentralized and politically neutral structures; consistently, even during political instability, without impeding (indeed supporting) the private sector.

Many find this word picture appealing - the kind of government one would comfortably call 'good'. One should note how clearly it reflects the characteristics of what externally influenced reforms posit are 'right rules' of the game of government. One should also note that these characteristics are considered generically relevant and 'good' for all countries. Other indicators are similar. The World Bank's Country Policy and Institutional Assessment (CPIA) grades countries against common characteristics in twenty criteria areas that represent "policy and institutional dimensions of an effective poverty reduction and growth strategy." 46 The CPIA focuses explicitly on policies and institutional arrangements, considered "the key elements that are within the country's control" given a belief that, "Good policies and institutions are expected to lead, over time, to favorable growth and poverty reduction outcomes." 47 Criteria are generic, specific and reward countries with market-friendly, ${ }^{48}$ disciplined, modern and formal institutions. For example, the top score on criteria 15- the quality of public administrationrequires disciplined, modern and formal institutions where:

a. Effective coordination mechanisms ensure a high degree of policy consistency across departmental boundaries.

b. Organizational structures are along functional lines with very little duplication. Business processes are regularly reviewed to ensure efficiency of decision making and implementation.

\footnotetext{
${ }^{46} \mathrm{http}: / /$ siteresources.worldbank.org/IDA/Resources/CPIA2007Questionnaire.pdf, page 1.

${ }^{47}$ CPIA questionnaire, page 4.

${ }^{48}$ For example, the top score of criteria 6 - a measure of the 'Business regulatory environment'-requires marketfriendly rules of the game: a. Almost no bans or investment licensing requirements. Regulations facilitate efficient entry and exit of business. Good legal framework to address anti-competitive conduct by firms exists, and is consistently enforced. All public sector entities are free to procure from any source. b. Streamlined industry licensing, permits, and inspections requirements facilitate business activity. State intervention in the goods market is limited to regulation and/or legislation to smooth out market imperfections. Corporate governance laws encourage disclosure and protect shareholder rights and are enforced effectively. c. Employment law provides a high degree of flexibility to hire and fire at low cost. Other labor market institutions facilitate doing business. State intervention in the labor and land markets is limited to regulation and/or legislation to smooth out market imperfections. Procedures to register property are simple, low cost, and fast.
} 
c. Hiring and promotion are based on merit and performance, and ethical standards prevail.

d. The wage bill is sustainable and does not crowd out spending required for public services.

e. $\quad$ Pay and benefit levels do not deter talented people from entering the public sector.

f. There is flexibility (that is not abused) in paying more attractive wages in hard to fill positions (e.g. rural teachers, technical specialists).

Doing Business indicators similarly reward countries with light regulatory burdens and limited government economic engagement. Governments are given titles such as 'Best Reformer' when they introduce changes to introduce good practice, framed as conformity with a limited and disciplined 'rules of the game' world. Donor-created Public Expenditure and Financial Accountability (PEFA) indicators also define common and specific mechanisms that constitute "good international practices...critical...for all countries to achieve sound public financial management." 49 Countries are rewarded if they introduce 'rules' embedded in formal budget preparation processes, treasury management systems, internal audit mechanisms, standardized accounting systems, and the like.

These and other indicators constitute pictures of good government. These pictures provide a view of the 'right rules' of government that is both common and consistent with the view reflected in reforms influenced by international organizations. Indicators thus reinforce reforms and embed a common and particular one-best-way model of what government should look like to facilitate development. It is this model that international organizations have increasingly used to influence government solutions in developing countries across the world - in Chile and Uganda in the 1980s, Azerbaijan and Georgia in the 1990s, and Afghanistan in the 2000s. This influence has been growing as project numbers (and sizes) grow and as more and more indicators reinforce the idea that there is such a thing as 'good' or 'better' or 'best' international practice in thinking about and creating and shaping governments.

The discussion here should not be read as a critique of endorsement of the one-bestway model that seems to persist in development or even of the idea that international organizations are shaping the government solutions in place across the developing world. It

\footnotetext{
${ }^{49}$ PEFA 2006, 2.
} 
simply notes that it exists and is reflected in patterns of World Bank project data. Noting that it exists, however, causes one to ask a simple question: "What does it matter if international agencies are defining governmental solutions in developing countries?” In a sense this question has already been addressed in prior work that criticized one-best-way models without actually providing evidence of such. ${ }^{50}$ However, the discussion here should add substance to even these existing studies, giving an evidentiary basis to support those who have raised critiques and fuelling the discussion of whether international organizations are over-reaching their mandates - infringing on the sovereignty of these nations and frustrating domestic processes of finding and fitting government structures to local contexts.

\section{References}

Ahrens, J. (2001). Governance, Conditionality and Transformation in Post-Socialist Countries. In H. Hoen (Ed.). Good Governance in Central and Eastern Europe. Cheltenham: Edward Elgar, 54-90.

Andrews, M. (2005). Performance-Based Budgeting Reform. In Shah, A. (ed.) Fiscal Management, Public Sector Governance and Accountability Series. Washington, D.C.: The World Bank.

Andrews, M. (2008). The Good Governance Agenda. Beyond Indicators Without Theory. Oxford Development Studies 36(4), 379-407.

Andrews, M. (2009). Isomorphism and the limits to African public financial management reform. Harvard Kennedy School Working Paper. Working Paper No. RWP09-012.

Andrews, M. (2010). Good Government Means Different Things in Different Countries. Governance 23(1), 7-35

Andrews, M. (2011). Which organizational attributes are amenable to external reform? An empirical study of African public financial management. International Public Management Journal, Vol 5(2), 135-154.

\footnotetext{
${ }^{50}$ Including my own work in Andrews $(2008,2010)$.
} 
Andrews, M. (2013). The Limits of Institutional Reform in Development. New York, N.Y.: Cambridge.

Chang, H. J. (2003). Kicking Away the Ladder: Infant Industry Promotion in Historical Perspective 1. Oxford Development Studies 31(1), 21-32.

Grindle, M. (2004). Good Enough Governance: Poverty Reduction and Reform in Developing Countries. Governance: An International Journal of Policy, Administration and Institutions $17,525-548$.

Kaufmann, D., Kraay, A., and Mastruzzi, M. (2007). Governance Matters VI: Aggregate and Individual Governance Indicators 1996-2006. World Bank Policy Research Working Paper, No. 4280. Washington, DC.

Kenny, K. (2008). Arrive Bearing Gifts. In S. Dar and B. Cooke (Eds.). The New Development Management: Critiquing the Dual Modernization. London: Zed Books.

Knack, S. (2000., Aid dependence and the quality of governance: a cross-country empirical analysis, No 2396, Policy Research Working Paper Series, The World Bank, http://EconPapers.repec.org/RePEc:wbk:wbrwps:2396.

Moloney, K. (2009). Public Administration and Governance: A Sector-Level Analysis of World Bank Aid. International Review of Administrative Sciences 75(4), 609-627.

North, D. (1990). Institutions, Institutional Change and Economic Performance. Cambridge: Cambridge University Press.

PEFA. (2006). Public Expenditure and Financial Accountability Performance Measurement Framework. http://www.pefa.org/pfm_performance_file/the_framework_English_1193152901.pdf.

Rodrik, D. (2007). One Economics, Many Recipes: Globalization, Institutions, and Economic Growth. Princeton: Princeton University Press.

Rose, R. (2003). What's Wrong with Best Practice Policies - And Why Relevant Practices Are Better. On Target? Government by Measurement. London: House of Commons Public Administration Select Committee HC 62-II, 2003, 307-317.

World Bank. (1988). Public Finance in Development: 1988 World Development Report. New York: Oxford University Press. 
World Bank. (1992). Governance and Development. Washington, DC: World Bank.

World Bank. (2000). Reforming Public Institutions and Strengthening Governance. A World Bank Strategy. Washington, DC: World Bank.

World Bank. (2008). Public Sector Reform: What Works and Why? Washington, DC: World Bank.

Yeager, T. J. (1999). Institutions, Transition Economies and Economic Development. Boulder: Westview Press. 